\title{
Impairments in Brain-to-Blood Transport of Amyloid- $\beta$ and Reabsorption of Cerebrospinal Fluid in an Animal Model of Alzheimer's Disease are Reversed by Antisense Directed Against Amyloid- $\beta$ Protein Precursor
}

\author{
William A. Banks ${ }^{\mathrm{a}, *}$, Vijaya B. Kumar ${ }^{\mathrm{b}}$, Susan A. Farr ${ }^{\mathrm{b}}$, Ryota Nakaoke ${ }^{\mathrm{c}}$, Sandra M. Robinson ${ }^{\mathrm{b}}$ \\ and John E. Morley ${ }^{\mathrm{b}}$ \\ ${ }^{a}$ GRECC, Veterans Affairs Puget Sound Health Care System and University of Washington School of Medicine, \\ Division of Gerontology and Geriatric Medicine, Department of Internal Medicine, Seattle, WA, USA \\ ${ }^{\mathrm{b}}$ GRECC, Veterans Affairs Medical Center-St. Louis and Saint Louis University School of Medicine, \\ Division of Geriatrics, Department of Internal Medicine, St. Louis, MO, USA \\ ${ }^{\mathrm{c}}$ Department of Pharmacology 1, Nagasaki University School of Medicine, Nagasaki, Japan
}

Accepted 7 October 2010

\begin{abstract}
The blood-brain barrier (BBB) influences brain levels of amyloid- $\beta$ (A $\beta$ ) by transporting A $\beta$ out of the brain (efflux) and by the reabsorption of cerebrospinal fluid (CSF) into the blood stream (bulk flow). In Alzheimer's disease (AD) and normal aging, unknown factors impair $A \beta$ efflux and bulk flow in aging and in $A D$. These impairments have been proposed as mechanisms by which the $A \beta$ burden in brain can increase. Impairment in $A \beta$ efflux occurs in animal models of $A D$, including the aged SAMP8 mouse. Here, we show that CSF reabsorption is also reduced by about $50 \%$ in SAMP8 mice $(p<0.05)$. We then determined whether an antisense directed at the $A \beta$ region of the amyloid- $\beta$ protein precursor (A $\beta P P)$ and previously shown to decrease brain levels of A $\beta P P$ and to reverse the cognitive impairments of the SAMP8 mouse was able to reverse these impairments. We found that the antisense restored both the CSF reabsorption, more than doubling the rate of efflux, and the saturable efflux of $A \beta$. These findings suggest that $A \beta P P / A \beta$ itself contributes to the impairments in bulk flow and saturable efflux of $A \beta$ and that reduction of $A \beta P P / A \beta$ levels can restore normal function of the BBB.
\end{abstract}

Keywords: Alzheimer's disease, amyloid- $\beta$ protein precursor, antisense, blood-brain barrier, bulk flow, SAMP8

\section{INTRODUCTION}

Amyloid- $\beta$ (A $\beta)$ has increasingly emerged as a major candidate in the pathophysiology of Alzheimer's disease $(\mathrm{AD})$ [1]. One mechanism suggested to contribute to the accumulation of $A \beta$ in brain is a defect in

\footnotetext{
*Correspondence to: William A. Banks, GRECC, VAPSHCS, Room 810A, 1600 S. Columbian Way, Seattle, WA 98108, USA. E-mail:wabanks1@uw.edu.
}

its clearance from brain [2-4]. A $\beta$ is cleared from brain by saturable and nonsaturable mechanisms [5-11]. Both P-glycoprotein $[12,13]$ and low density lipoprotein receptor-related protein-1 (LRP) are located at the blood-brain barrier (BBB) $[6,14]$ and have been suggested to be the saturable transporters for $A \beta$ brain efflux. Histological studies show a decrease in LRP activity in human BBB tissue taken from AD patients $[6,15]$, providing a mechanism to explain the 
decreased efflux of $A \beta$ in AD. Knockdown of LRP function at the $\mathrm{BBB}$ results in decreased $\mathrm{A} \beta$ efflux, increased $A \beta$ levels in the brain, and cognitive impairments in otherwise normal mice [16]. Nonsaturable efflux occurs with reabsorption of cerebrospinal fluid (CSF), termed bulk flow [17]. Bulk flow is decreased in both $\mathrm{AD}$ and healthy aging [18-20]. Thus, impairments in both the saturable and non-saturable clearance of $A \beta$ from the central nervous system (CNS) could substantially increase the accumulation of $A \beta$ in the CNS. The underlying mechanisms of these impairments are currently unknown.

The SAMP8 mouse, an animal model of AD, has an impaired efflux of $A \beta$ [10]. The SAMP8 strain has a natural mutation that induces with aging an overexpression of amyloid- $\beta$ protein precursor (A $\beta P P)$ [21-23]. The A $\beta P P$ also has a single amino acid substitution of an alanine for a valine at position 300 [24]. Although cognitively normal at 2 mo of age, SAMP8 mice develop age-dependent deficits in learning and memory that are severe by 12 mo of age [25]. Cholinergic defects, resistance to the memory enhancing effects of cholinergics, amyloid deposits, alterations in membrane fatty acids and in delta-9-desaturase activity, and oxidative stress to critical proteins have been found in the SAMP8 mouse [26-30]. Many of these problems, including the cognitive deficits, elevated A $\beta P P$ levels, and oxidative stress, can be reversed by treating mice with either antisense directed against the $A \beta$ region of $A \beta P P$ or antibody directed against $A \beta[21,23,31-$ 34]. The SAMP8 mouse also has a decreased capacity to transport murine $A \beta_{1-42}$ at a young age [10] that worsens with age.

The decreased ability of the SAMP8 mice to efflux $A \beta$ could be caused by impairment in the saturable transport, the bulk flow efflux of $A \beta$, or both. The deficit in transport at an early age raises the possibility that early increases in $A \beta$, the mutation in $\mathrm{A} \beta \mathrm{PP}$, or altered processing of A $\beta \mathrm{PP}$ may act to impair its own efflux. Here, we addressed two questions: 1) Whether bulk flow is impaired in aged SAMP8 mice; and 2) Whether the impaired brain-to-blood efflux of $A \beta$ could be reversed with antisense directed against A $\beta P P$.

\section{METHODS}

\section{Iodination of $A \beta$ and albumin}

Five $\mu g$ of carrier-free, recombinant murine $A \beta_{1-42}$ (American Peptide Co, Sunnyvale, CA) was radioactively labeled with ${ }^{131} \mathrm{I}$ by the chloramine-T method.
The radioactively labeled $A \beta$ (I-A $\beta$ ) was purified and separated from unincorporated iodine on a column of G-10 Sephadex by eluting $0.1 \mathrm{ml}$ fractions with protein-free, chloride-free phosphate buffer solution. Previous work showed that about $70 \%$ of the I-A $\beta$ was in the monomeric form, the form of $A \beta$ most likely to be transported across the BBB [10]. Albumin was also labeled with ${ }^{131} \mathrm{I}$ by the chloramine- $\mathrm{T}$ method and the radioactive albumin (I-Alb) purified on a G-10 Sephadex column.

\section{Measurement of efflux rates}

The method has been previously used to quantify efflux of $A \beta$ [35-38]. Two month old male ICR mice, two month old SAMP8 mice, or twelve month old SAMP8 mice (all from our in-house colonies) were kept on a 12/12 hour light/dark cycle with food and water freely available. They were anesthetized on day of study with $0.15 \mathrm{ml}$ of $40 \%$ urethane. The scalp was removed and a hole made into the lateral ventricle, $1.0 \mathrm{~mm}$ lateral and $1.0 \mathrm{~mm}$ posterior to the bregma, with a 26 gauge needle with a tubing guard which kept the depth of the holes constant (3.0-3.5 mm). Mice received $1.0 \mu \mathrm{l}$ intracerebroventricular (icv) injections containing $5\left(10^{3}\right) \mathrm{cpm}$ (about $0.125 \mathrm{ng}$ ) of I-A $\beta$ in a lactated Ringer's solution with $1 \%$ bovine serum albumin or containing $3\left(10^{5}\right) \mathrm{cpm}$ of $\mathrm{I}-\mathrm{Alb}$. An inhibitory component to A $\beta$ efflux was tested by including $1 \mu \mathrm{g} /$ mouse of unlabeled $\mathrm{A} \beta$ in the injection. Mice were decapitated at 2, 5, 10, and 20 min after injection. For I-Alb, an additional group was decapitated at $30 \mathrm{~min}$. The whole brain was removed, the pituitary and pineal glands were discarded, and the level of residual radioactivity in the whole brain was determined from the counts after $3 \mathrm{~min}$ in a gamma counter. The level of radioactivity in whole brain at $t=0$ was determined in mice overdosed with anesthetic as previously described [35]. The cpm remaining in the brain was divided by the cpm injected and multiplied by 100 to yield the percent of the injected dose remaining in brain (\% Inj/brain). The log of \% Inj/brain was regressed against time. A significant correlation between $\log (\%$ Inj/brain) and time indicated a measurable efflux from brain to blood of the injected substance, with the slope $(\mathrm{m})$ of this relation measuring the rate of efflux.

\section{Antisense treatment regimen}

A 42mer phosphorothioate oligodeoxynucleotide antisense directed at $\mathrm{A} \beta_{17-30} \quad\left(5^{\prime}\left(\_\mathrm{P}=\mathrm{S}\right) \mathrm{GGCGCC}\right.$ TTTGTTCGAACCCACATCTTCAGCAAAGAACA 
CCAG-3') was synthesized by the Midland Certified Reagent Co (Midland, TX) by use of cyanoethyl phosphoramidite chemistry. SAMP8 mice (2 or 12 mo old) were given injections into the tail vein of $0.2 \mathrm{ml}$ saline without (control) or with $6 \mu \mathrm{g}$ of the antisense. Tail vein injections were repeated twice at two week intervals. I-A $\beta$ and I-Alb efflux rates were measured 2 weeks after the final ( 3 rd dose) of antisense.

\section{Statistical analysis}

Means are reported with the number of mice used ( $n$ ) and the standard error of the mean (SEM). Student's $t$-test was used for comparison of two groups. More than two groups were compared by analysis of variance (ANOVA) followed by Newman-Keuls post test. The $p$ values were reported for relevant statistically significant differences. Regression lines were calculated by the least squares method with the Prism 5.0 program (GraphPad, Inc., San Diego, CA) and the slope $(m)$ with its standard deviation of the mean with its error term, the correlation coefficient $(r)$, the number of points on which the line was based $(n)$ and the $p$ value reported. Slopes were compared by $t$-test unless there were more than two slopes, which were compared by ANOVA followed by Newman-Keuls post test. The standard deviation of the mean was taken as the standard error term and, because two means (the slope and the intercept) were calculated from the data, $n-1$ was used as the value for $n$.

\section{RESULTS}

We first compared the efflux of I-Alb in 2 mo old CD-1 mice, 2 mo old SAMP- 8 mice, and 12 mo old SAMP8 mice (Fig. 1). The 12 mo old SAMP8 mice in comparison to either of the 2 mo old strains have increased $A \beta$ burden, cognitive impairment, oxidative stress, decreased acetylcholine, and impaired clearance of $\mathrm{A} \beta[21,23,30,32,39,40]$. A statistically significant relation existed between $\log (\%$ Inj/brain) and time for all three groups, demonstrating a measurable brain-to-blood efflux of I-Alb [CD-1: $m,=$ $-0.0172 \pm 0.008, r=0.937, n=12, p<0.001$; SAM-2 mo: $m=-0.00846 \pm 0.002, r=0.806, n=12 . p<0.005$; SAM-12 mo: $-0.0106 \pm 0.002, \quad r=0.825, \quad n=12$, $p=0.001]$. Upper panel of Fig. 1 illustrates the efflux curve for CD-1 mice. Comparison of these slopes by ANOVA showed a significant difference among the slopes of three groups $[F(2,30)=4.67, p<0.05]$, showing that the rate of efflux varied among the three groups. Newman-Keuls post test showed that efflux measured as the slope $[(-) \log (\%$ Inj/brain $) /$ time $]$ in $\mathrm{CD}-1$ mice

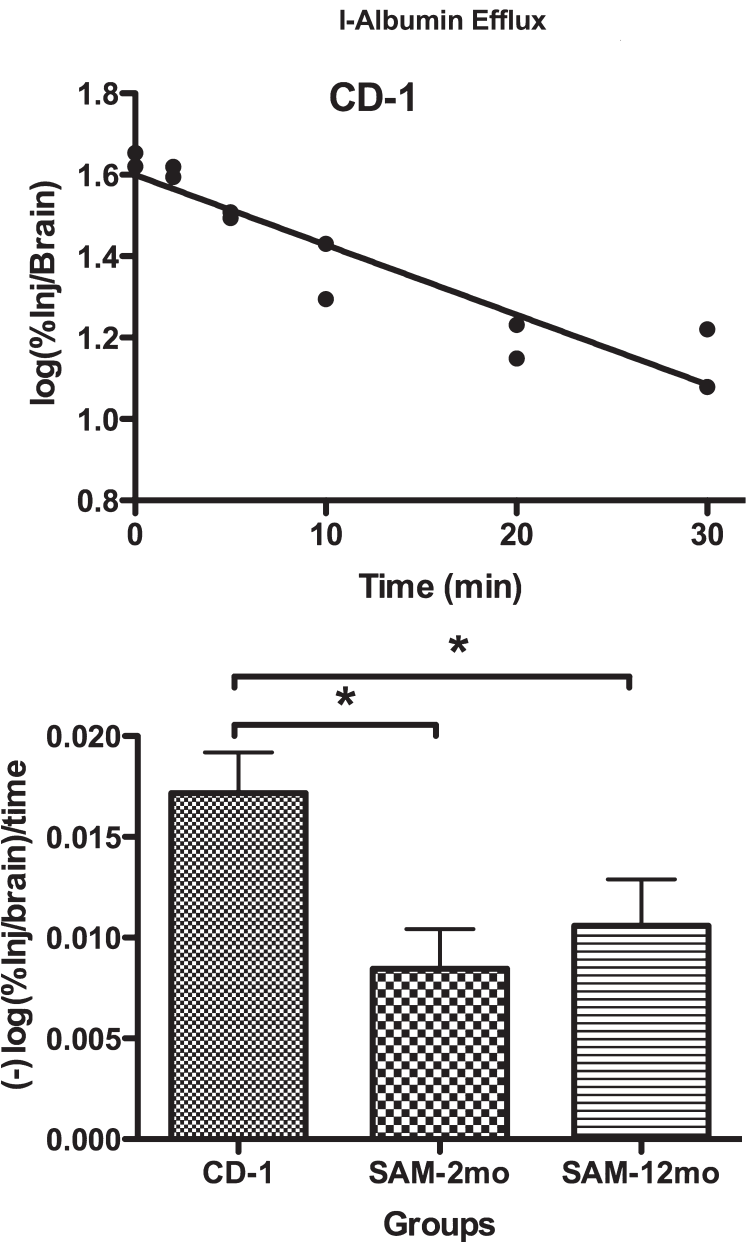

Fig. 1. Clearance of I-Alb from Brain. Upper panel shows an example of time-curve data used to generate slope, which measures clearance from brain. Lower panel shows slopes measured in units of [(-) $\log (\%$ Inj/brain)/time] for CD-1, 2 mo old SAMP8 mice and 12 mo old SAMP8 mice. The lower values for slopes in the SAMP8 mice demonstrate a statistically significant $(* p<0.05)$ slower rate of clearance from brain that was reduced by about $50 \%$.

was faster than in either group of SAMP8 $(p<0.05)$, whereas there was no difference between the two ages of SAMP8 (Fig. 1, bottom panel).

The effect of antisense treatment on I-Alb efflux from the brains of 12 mo old SAMP8 mice is shown in Fig. 2. Antisense significantly increased efflux of I-Alb $(p<0.05)$. Brain weights did not differ between these two groups.

The relation between the $\log (\%$ Inj/brain) for I-A $\beta$ and time in 2 mo old SAMP8 mice not treated with antisense was not statistically significant, demonstrating a lack of measurable brain-to-blood efflux (Fig. 3, upper panel). In mice treated with antisense, the relation between $\log (\%$ Inj/brain) for I-A $\beta$ and time was statistically significant $(m=-0.0099 \pm 0.0025, r=0.818$, 


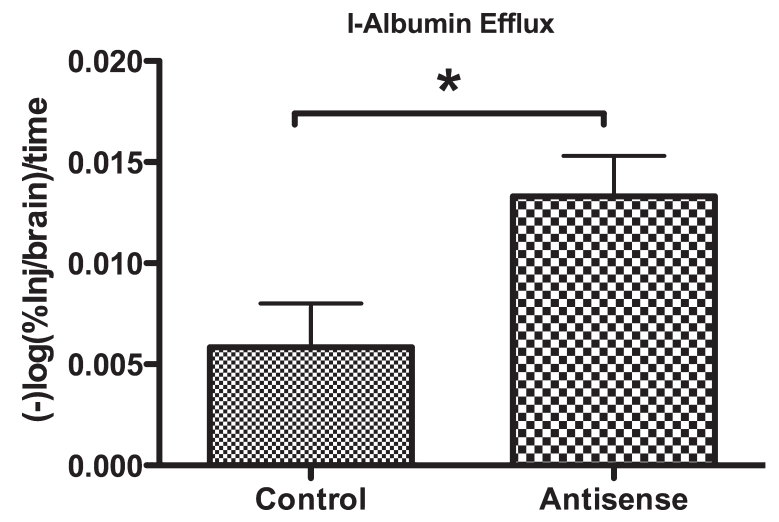

Fig. 2. Effect of Antisense on I-Alb clearance in 12 mo old SAMP8 mice. Antisense increased the rate of clearance of I-Alb by about two fold $(p<0.05)$.

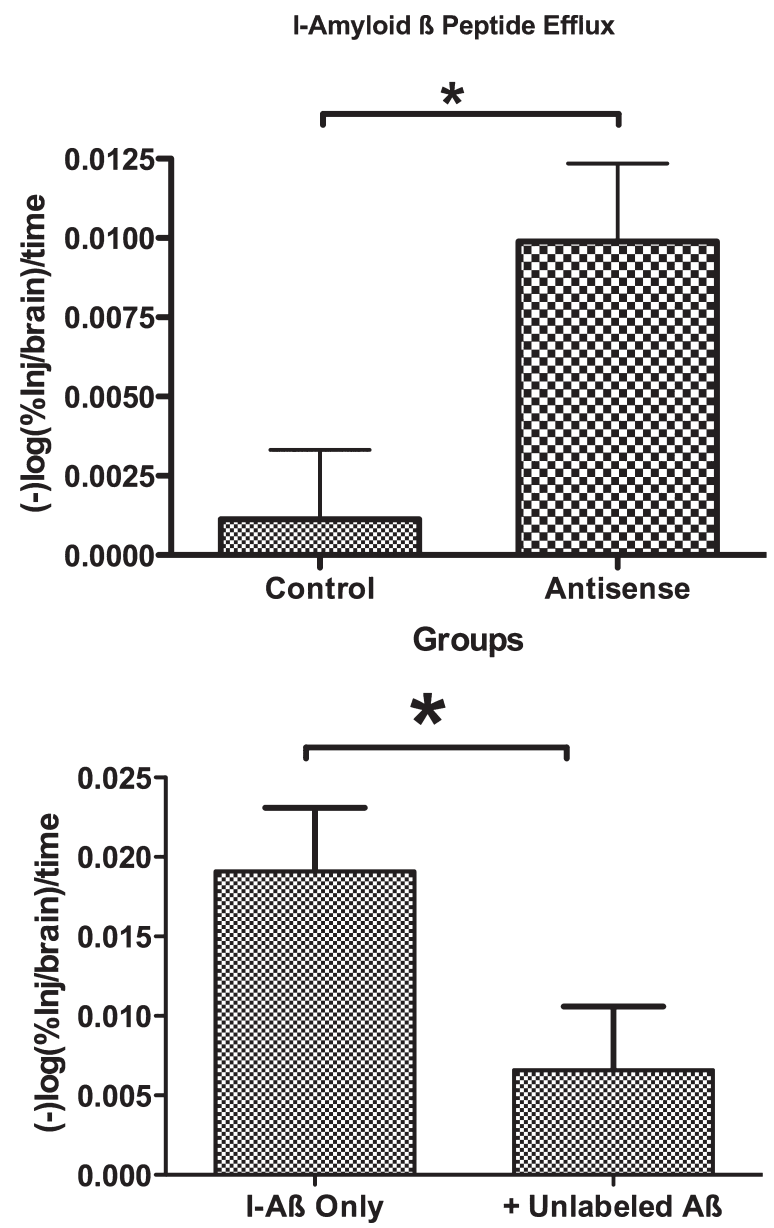

Fig. 3. Effect of Antisense on Efflux of I-A $\beta$ from Brain in 2 mo old SAMP8 mice. Upper panel shows that antisense treatment restored efflux of radioactively labeled murine $A \beta_{1-42}$ from brain $(p<0.05)$. Lower panel shows that in antisense-treated mice, unlabeled $A \beta$ inhibits I-A $\beta$ efflux from brain $(p<0.05)$. This confirms that antisense increased $A \beta$ efflux by restoring the saturable mechanism. $n=10, p<0.005)$. These lines were significantly different by $t$-test $(p<0.05)$. As a control, antisense was injected 5 min before an icv injection of I-A $\beta$ in 2 mo old CD-1 mice. Antisense produced no change in the $\log (\%$ Inj/brain) for I-A $\beta$ in brains harvested $15 \mathrm{~min}$ after the icv injection.

To determine whether the increased efflux of I-A $\beta$ treatment involved restoration of the saturable $A \beta$ transporter, we included unlabeled $A \beta$ ( $1 \mu \mathrm{g} /$ mouse $)$ in the injection of 2 mo old SAMP8 mice treated with antisense. The $t$-test showed a significant inhibition $(p<0.05)$ in efflux with unlabeled $\mathrm{A} \beta$ (Fig. 3, lower panel). This demonstrates that the increase in efflux of $A \beta$ induced by antisense was caused by the re-establishment of the saturable process.

\section{DISCUSSION}

Impaired efflux of $A \beta$ by saturable and nonsaturable mechanisms could contribute to the $A \beta$ burden in brains of AD patients. The major findings of the current study are i) bulk flow is decreased in the SAMP8 mouse, ii) antisense directed against $A \beta P P$ reverses the impairment in brain-to-blood efflux of $A \beta$ in the SAMP8 mouse, iii) antisense restores the saturable efflux of $A \beta$. These findings suggest that $A \beta$ itself is responsible for both the impairment of its own transporter and for inhibition of bulk flow.

CSF slowly enters the blood stream by reabsorption at the arachnoid villi and the cribriform plate [41]. This reabsorption is termed bulk flow and its rate is classically measured by the use of radioactively labeled albumin as we did here [17]. The slow, nonsaturable reabsorption of CSF, termed bulk flow, could also allow toxic substances other than $A \beta$ to accumulate by decreasing their clearance from the brain. Decreased bulk flow can also explain the higher $\mathrm{CSF} /$ serum ratios for albumin often noted in AD patients [20] and often assumed to be BBB disruption. Restoration of the clearance of CSF, and especially restoration of the clearance of $A \beta$, would likely improve cognitive function in models of $\mathrm{A} \beta$ toxicity. As such, correction of decreased bulk flow has been suggested as a treatment of $\mathrm{AD}$ [19]. The current results are consistent with this conjecture, as we have previously found that this antisense improves cognitive functioning in the SAMP8 mouse [10, 21, 31].

The saturable clearance of $A \beta$ and its impairment in $\mathrm{AD}$ is well documented by several laboratories [5-7, 10, 42]. Two BBB transporters have been implicated in $A \beta$ efflux, LRP-1 and P-gp $[6,7,12,13]$. Inhibition of LRP-1 in young, normal mice results in decreased 
efflux of $A \beta$ from brain, increased $A \beta$ levels in brain, and cognitive impairments [16]. Here, we showed that treatment of SAMP8 mice not only increased the rate of I-A $\beta$ efflux, but that the increase was attributable to a process inhibited by unlabeled $A \beta$. This inhibition by unlabeled $A \beta$ demonstrates that the increased flux of radioactivity was not explicable only by an increase in bulk flow or other transporters such as that for free iodine.

The antisense used here is a phosphorothioated molecule directed at $A \beta_{17-30}$. It decreases $A \beta P P$ and $A \beta$ levels in the brains of SAMP8 mice [21, 34]. The antisense does not affect the levels of other substances and its reverse antisense is without effect [21, 43]. This antisense is stable in blood with a long residence time in blood and peripheral tissues [31]. It is transported across the blood-brain barrier by a saturable system and can reverse the cognitive impairments and oxidative stresses found in the SAMP8 mouse after ICV or IV administration [21, 31, 34]. The method used to assess efflux is well described and has been widely used to measure brain-to-blood transport [35, 36, 4447]. Because the material to be assessed is injected into the lateral ventricle of the brain, transporters at both periventricular microvasculature and choroid plexus as well as bulk flow are assessed [48-50]. The rates calculated by this method are not indices, but measure efflux rates that are identical to those assessed by the gold standard of rate of appearance in blood [51]. We assessed $A \beta_{1-42}$ here, rather than $A \beta_{1-40}$, as it is considered to be the more toxic form of $A \beta$.

The causes for the decrease in bulk flow and saturable efflux of $\mathrm{A} \beta$ in normal aging or $\mathrm{AD}$ are unknown. The results presented here suggest that $A \beta P P$ or $A \beta$ itself is responsible for this decrease in bulk flow as well as the decrease in $A \beta$ efflux. $A \beta$ could affect $\mathrm{BBB}$ function through several mechanisms. For example, $A \beta$ can cause formation of ion channels and induce oxidative stress. Bulk flow is a hydrostatic process that depends on CSF formation and requires the ion magnesium and altered ion transport and oxidative stress have been proposed to explain age-related decreases in CSF turnover [52]. Oxidative stress could result in damage to $A \beta$ transporters as well as to the cellular machinery responsible for bulk flow. SAMP8 mice show increased oxidative stress which is reversed with antisense to A $\beta$ [34]. Furthermore, the antioxidant alpha lipoic acid reverses both the cognitive impairments and the oxidative stress seen in the SAMP8 [40, 53]. These mechanisms are consistent with in vitro work showing that $A \beta$ can enhance proteasome-dependent degradation of LRP, one of the candidate transporters for $A \beta$
[54]. Additionally, A $\beta$ can interfere with cytoskeletal arrangement which is critical to the functioning of the BBB [55].

In conclusion, we found that bulk flow (CSF reabsorption) is impaired in the aged SAMP8 mouse, an animal model of AD. Treatment with antisense directed at $A \beta$ region of $A \beta P P$ not only restores bulk flow, but also restores the previously described deficit in the saturable efflux of $A \beta$. These results suggest that among the CNS lesions induced by $\mathrm{A} \beta$ are two deficits in BBB function: impaired reabsorption of CSF and impaired saturable clearance of $A \beta$. Both of these deficits would contribute to the accumulation by the CNS of toxic materials, including $A \beta$.

\section{ACKNOWLEDGMENTS}

Supported by VA and NIA R01 AG029839.

Authors' disclosures available online (http://www.jalz.com/disclosures/view.php?id=651).

\section{REFERENCES}

[1] Walsh DM, Selkoe DJ (2004) Deciphering the molecular basis of memory failure in Alzheimer's disease. Neuron 44, 181193.

[2] Zlokovic BV, Yamada S, Holtzman D, Ghiso J, Frangione B (2000) Clearance of amyloid $\beta$-peptide from brain: transport or metabolism? Nat Med 6, 718-719.

[3] Zlokovic BV (2004) Clearing amyloid through the bloodbrain barrier. J Neurochem 89, 807-811.

[4] Banks WA, Kastin AJ, Maness LM, Banks MF, Shayo M (1997) Interactions of beta-amyloids with the blood-brain barrier. Ann N Y Acad Sci 826, 190-199.

[5] Ghersi-Egea JF, Gorevic PD, Ghiso J, Frangione B, Patlak CS, Fenstermacher JD (1996) Fate of cerebrospinal fluid-borne amyloid $\beta$-peptide: rapid clearance into blood and appreciable accumulation by cerebral arteries. J Neurochem 67, 880-883.

[6] Shibata M, Yamada S, Kumar SR, Calero M, Bading J, Frangione B, Holtzman DM, Miller CA, Strickland DK, Ghiso J, Zlokovic BV (2000) Clearance of Alzheimer's amyloid- $\beta$ 1-40 peptide from brain by LDL receptor-related protein-1 at the blood-brain barrier. J Clin Invest 106, 14891499.

[7] DeMattos RB, Bales KR, Cummins DJ, Paul SM, Holtzman DM (2002) Brain to plasma amyloid- $\beta$ efflux: a measure of brain amyloid burden in a mouse model of Alzheimer's disease. Science 295, 2264.

[8] Bading JR, Yamada S, Mackic JB, Kirkman L, Miller C, Calero M, Ghiso J, Frangione B, Zlokovic BV (2002) Brain clearance of Alzheimer's amyloid- $\beta 40$ in the squirrel monkey: A SPECT study in a primate model of cerebral amyloid angiopathy. J Drug Target 10, 359-368.

[9] Pluta R, Misicka A, Barcikowska M, Spisacka S, Lipkowski AW, Januszewski S (2000) Possible reverse transport of beta-amyloid peptide across the blood-brain barrier. Acta Neurochir Suppl 76, 73-77.

[10] Banks WA, Robinson SM, Verma S, Morley JE (2003) Efflux of human and mouse amyloid $\beta$ proteins $1-40$ and 1-42 from 
brain: impairment in a mouse model of Alzheimer's disease. Neuroscience 121, 487-492.

[11] Tanzi RE, Moir RD, Wagner SL (2004) Clearance of Alzheimer's Abeta peptide: the many roads to perdition. Neuron 43, 608.

[12] Lam FC, Liu R, Shapiro AB, Renoir JM, Sharon FJ, Reiner PB (2001) Beta-Amyloid efflux mediated by p-glycoprotein. J Neurochem 76, 1121-1128.

[13] Vogelgesang S, Cascorbi I, Schroeder E, Pahnke J, Kroemer HK, Siegmund W, Kunert-Keil C, Walker LC, Warzok RW (2002) Deposition of Alzheimer's beta-amyloid is inversely correlated with p-glycoprotein expression in the brains of elderly non-demented humans. Pharmacogenetics 12, 535541.

[14] Deane R, Wu Z, Sagare A, Davis J, Du Yan S, Hamm K, Xu F, Parisi M, LaRue B, Hu HW, Spijkers P, Guo H, Song X, Lenting PJ, Van Nostrand WE, Zlokovic B (2004) LRP/amyloid beta-peptide interaction mediates differential brain efflux of Abeta isoforms. Neuron 43, 333-344

[15] Donahue JE, Flaherty SL, Johanson CE, Duncan JA 3rd, Silverberg GD, Miller MC, Tavares R, Yang W, Wu Q, Sabo E, Hovanesian V, Stopa EG (2006) RAGE, LRP-1, and amyloidbeta protein in Alzheimer's disease. Acta Neuropathol 112, 405-415.

[16] Jaeger LB, Dohgu S, Hwang MC, Farr SA, Murphy MP, Fleegal-DeMotta MA, Lynch JL, Robinson SM, Niehoff ML, Johnson SN, Kumar VB, Banks WA (2009) Testing the neurovascular hypothesis of Alzheimer's disease: LRP-1 antisense reduces blood-brain barrier clearance and increases brain levels of amyloid beta protein and impairs cognition. J Alzheimers Dis 17, 553-570.

[17] Davson H, Segal MB (1996) The return of the cerebrospinal fluid to the blood: the drainage mechanism. In Physiology of the CSF and Blood-Brain Barriers, Davson H, Segal MB, eds. CRC Press, Boca Raton, pp. 489-523.

[18] Silverberg GD, Heit G, Huhn S, Jaffe RA, Chang SD, BronteStewart H, Rubenstein E, Possin K, Saul TA (2001) The cerebrospinal fluid production rate is reduced in dementia of the Alzheimer's type. Neurology 57, 1763-1766.

[19] Silverberg GD, Levinthal E, Sullivan EV, Bloch DA, Chang SD, Leverenz J, Flitman S, Winn R, Marciano F, Saul T, Huhn S, Mayo M, McGuire D (2002) Assessment of low-flow CSF drainage as a treatment for AD: results of a randomized pilot study. Neurology 59, 1139-1145.

[20] May C, Kaye JA, Atack JR, Schapiro MB, Friedland RP, Rapoport SI (1990) Cerebrospinal fluid production is reduced in healthy aging. Neurology 40, 500-503.

[21] Kumar VB, Farr SA, Flood JF, Kamlesh V, Franko M, Banks WA, Morley JE (2000) Site-directed antisense oligonucleotide decreases the expression of amyloid precursor protein and reverses deficits in learning and memory in aged SAMP8 mice. Peptides 21, 1769-1775.

[22] Morley JE, Farr SA, Kumar VB, Banks WA (2002) Alzheimer's disease through the eye of a mouse: Acceptance lecture for the 2001 Gayle A Olson and Richard D Olson prize. Peptides 23, 589-599.

[23] Morley JE, Kumar VB, Bernardo AF, Farr SA, Uezu K, Tumosa N, Flood JF (2000) $\beta$-Amyloid precursor polypeptide in SAMP8 mice affects learning and memory. Peptides 21, 1761-1767.

[24] Kumar VB, Vyas K, Franko M, Choudhary V, Buddhiraju C, Alvarez J, Morley JE (2000) Molecular cloning, expression and regulation of hippocampal amyloid precursor protein of senescence accelerated mouse (SAMP8). Biochem Cell Biol 79, 57-67.
[25] Flood JF, Morley JE (1998) Learning and memory in the SAMP8 mouse. Neurosci Biobehav Rev 22, 1-20.

[26] Kumar VB, Wyas K, Buddhiraju M, Alshaher M, Flood JF, Morley JE (1999) Changes in membrane fatty acids and delta-9 desaturase in senescence accelerated (SAMP8) mouse hippocampus with aging. Life Sci 65, 1657-1662.

[27] Flood JF, Morley JE (1992) Early onset of age-related impairment of aversive and appetitive learning in the SAM-P/8 mouse. J Gerontol 47, B52-B59.

[28] Flood JF, Morley JE (1994) Age-related changes in the pharmacological improvement of retention in SAMP8 mice. In The SAM Model of Senescence, Takeda T, ed. Excerpta Medica, Kyoto, pp. 89-94.

[29] Flood JF, Harris FJ, Morley JE (1996) Age-related changes in hippocampal drug facilitation of memory processing in SAMP8 mice. Neurobiol Aging 17, 15-24.

[30] Poon HF, Castegna A, Farr SA, Thongboonkerd V, Lynn BC, Banks WA, Morley JE, Klein JB, Butterfield DA (2004) Quantitative proteomics analysis of specific protein expression and oxidative modification in aged senescence-accelerated-prone 8 mice brain. Neuroscience 126, 915-926.

[31] Banks WA, Farr SA, Butt W, Kumar VB, Franko MW, Morley JE (2001) Delivery across the blood-brain barrier of antisense directed againt amyloid $\beta$ : reversal of learning and memory deficits in mice overexpressing amyloid precursor protein. J Pharmacol Exp Therap 297, 1113-1121.

[32] Farr SA, Banks WA, Uezu K, Sano A, Gaskin FS, Morley JE (2003) Antibody to beta-amyloid protein increases acetylcholine in the hippocampus of 12 month SAMP8 male mice. Life Sci 73, 555-562.

[33] Poon HF, Farr SA, Banks WA, Pierce WM, Klein JB, Morley JE, Butterfield DA (2005) Proteomic identification of less oxidized brain proteins in aged senescence-accelerated mice following administration of antisense oligonucleotide directed at the Abeta region of amyloid precursor protein. Mol Brain Res 138, 8-13.

[34] Poon HF, Joshi G, Sultana R, Farr SA, Banks WA, Morley JE, Calabrese V, Butterfield DA (2004) Antisense directed at the A-beta region of APP decreases brain oxidative markers in aged senescence accelerated mice. Brain Res 1018, 86-96.

[35] Banks WA, Kastin AJ (1989) Quantifying carrier-mediated transport of peptides from the brain to the blood. In Methods in Enzymology, Conn PM, ed. Academic Press, San Diego, vol 168, pp. 652-660.

[36] Banks WA, Fasold MB, Kastin AJ (1997) Measurement of efflux rate from brain to blood. In Methods in Molecular Biology: Neuropeptides Protocols, Irvine GB, Williams CH, eds. Humana Press, Totowa, NJ, pp. 353-360.

[37] Banks WA, Broadwell RD (1994) Blood to brain and brain to blood passage of native horseradish peroxidase, wheat germ agglutinin and albumin: pharmacokinetic and morphological assessments. J Neurochem 62, 2404-2419.

[38] Cashion MF, Banks WA, Kastin AJ (1996) Sequestration of centrally administered insulin by the brain: effects of starvation, aluminum, and TNF- $\alpha$. Horm Behav 30, 280-286.

[39] Flood JF, Morley JE, La Reginna M (1993) Age-related changes in the pharmacological improvement of retention in senescence accelerated mouse (SAM). Neurobiol Aging 14, 159-166.

[40] Poon HF, Farr SA, Thongboonkerd V, Lynn BC, Banks WA, Morley JE, Butterfield DA (2005) Proteomic analysis of specific brain proteins in aged SAMP8 mice treated with alpha-lipoic acid: implications for aging and age- 
related neurodegenerative disorders. Neurochem Int 46, 159-168.

[41] Boulton M, Flessner M, Armstrong D, Mohamed R, Hay J, Johnston M (1999) Contribution of extracranial lymphatics and arachnoid villi to the clearance of a CSF tracer in the rat. Am J Physiol 276, R818-R823.

[42] Ito S, Ohtsuki S, Terasaki T (2006) Functional characterization of the brain-to-blood efflux clearance of human amyloid-beta peptide (1-40) across the rat blood-brain barrier. Neurosci Res 56, 246-252.

[43] Banks WA, Kumar VB, Morley JE (2004) Influence of ethanol dependence and methionine enkephalin antisense on serum endomorphin-1 and methionine enkephalin levels. Alcohol Clin Exp Res 28, 792-796.

[44] Durham DA, Banks WA, Kastin AJ (1991) Carrier-mediated transport of labeled oxytocin from brain to blood. Neuroendocrinology 53, 447-452.

[45] Kastin AJ, Fasold MB, Zadina JE (2002) Endomorphins, Metenkephalin, Tyr-MIF-1 and the P-glycoprotein efflux system. Drug Metab Disposition 30, 231-234.

[46] Martins JM, Banks WA, Kastin AJ (1997) Acute modulation of the active carrier-mediated brain to blood transport of corticotropin-releasing hormone. Am J Physiol 272, E312E319.

[47] Taylor EM, Otero DA, Banks WA, O'Brien JS (2000) Designing stable, blood-brain barrier-permeable Prosaptide ${ }^{\mathrm{TM}}$ peptides for treatment of central nervous system neurodegeneration. J Pharmacol Exp Therap 293, 403-409.

[48] Maness LM, Banks WA, Zadina JE, Kastin AJ (1996) Periventricular penetration and disappearance of ICV Tyr-
MIF-1, DAMGO, tyrosine, and albumin. Peptides 17, 247250 .

[49] Maness LM, Kastin AJ, Farrell CL, Banks WA (1998) Fate of leptin after intracerebroventricular injection into the mouse brain. Endocrinology 139, 4556-4562.

[50] Segal MB, Preston JE, Collis CS, Zlokovic BV (1990) Kinetics and $\mathrm{Na}$ independence of amino acid uptake by blood side of perfused sheep choroid plexus. Am J Physiology 258, F1288-F1294.

[51] Banks WA, Kastin AJ (1992) Bidirectional passage of peptides across the blood-brain barrier. In Circumventricular Organs and Brain Fluid Environment, A Ermisch RL, Ruhle H-J, eds. Elsevier, Amsterdam, pp. 139-148.

[52] Preston JE (2001) Aging choroid plexus-cerebrospinal fluid system. Microsc Res Techn 52, 31-37.

[53] Farr SA, Poon HF, Dogrukol-Ak D, Drake J, Banks WA, Eyerman E, Butterfield DA, Morley JE (2003) The antioxidants alpha-lipoic acid and $\mathrm{N}$-acetylcysteine reverse memory impairment and brain oxidative stress in aged SAMP8 mice. J Neurochem 84, 1173-1183.

[54] Xie R, Hammarlund-Udenaes M, De Boer AG, de Lange EC (1999) The role of P-glycoprotein in blood-brain barrier transport of morphine: transcortical microdialysis studies in mdr1a (-/-) and mdr1a (+/+) mice. Br J Pharmacol 128, 563-568.

[55] Michaelis ML, Ansar S, Chen Y, Reiff ER, Seyb KI, Himes RH, Audus KL, Georg GI (2005) $\beta$-amyloid-induced neurodegeneration and protection by structurally diverse microtuble-stabilizing agents. J Pharmacol Exp Therap 312, 659-668. 